\title{
Absence of Expression of c-sis and Transforming Growth Factor- $\beta$ mRNA in Malignant Fibrous Histiocytoma
}

\author{
Thomas S. Frank, M.D., ${ }^{\star}$ John C. Reed, M.D., Ph.D., ${ }^{\dagger}$ and \\ John S. J. Brooks, M.D., MRCPath ${ }^{\dagger}$
}

\begin{abstract}
Total RNA was extracted from five malignant fibrous histiocytomas and two benign fibrohistiocytic lesions and assayed for mRNA expressions for transforming growth factor beta (TGF- $\beta$ ) and c-sis by Northern blot analysis. Production of both of these has been associated with cells of monocyte-macrophage lineage, and these factors have been shown to be important in physiologic mesenchymal cell proliferation. No mRNA expression of either TGF- $\beta$ or $c$-sis was identified in any of the fibrohistiocytic tumor samples. The lack of expression of TGF- $\beta$ and $c$-sis may be consistent with a nonhistiocytic origin of malignant fibrous histiocytoma, or may reflect transformationassociated loss of the normal molecular mechanisms of mesenchymal proliferation. The absence of c-sis mRNA expression can be reconciled with the prior immunohistochemical demonstration of platelet-derived growth factor in tumor cells of malignant fibrous histiocytoma. Int J Surg Pathol(2):117-122, 1993

Key words: malignant fibrous histiocytoma, c-sis, transforming growth factor beta, mRNA.
\end{abstract}

Transforming growth factor beta (TGF- $\beta$ ) is a highly conserved family of peptides ${ }^{1}$ that is constitutively expressed in both resting and activated monocytes and is secreted by the latter. ${ }^{2,3}$ Although the effects of TGF- $\beta$ are quite heterogeneous, ${ }^{4}$ TGF- $\beta$ is chemotactic for both fibroblasts and macrophages, ${ }^{5}$ and TGF- $\beta$ production by monocytes is thought to play a role in wound healing by stimulating angiogenesis and connective tissue elaboration. ${ }^{2,3,6,7}$ One of the effects of TGF- $\beta$ is autocrine stimulation of production of $\mathrm{c}$-sis by macrophages as well as by fibroblasts. ${ }^{3}$ c-sis encodes a precursor of the B chain of platelet-derived growth factor (PDGF), ${ }^{8}$ which is

From the * Department of Pathology, University of Michigan Medical School, Ann Arbor, Michigan, and the ${ }^{+}$Department of Pathology, University of Pennsylvania School of Medicine, Philadelphia, Pennsylvania.

Reprint requests: Thomas S. Frank, M.D., Department of Pathology, Room 2G332-0054, University of Michigan Medical Center, 1500 East Medical Center Drive, Ann Arbor, MI 48109-0054. a powerful mitogen of mesenchymal cells. ${ }^{9}$ In fact, the mitogenicity of TGF- $\beta$ is believed to be mediated by the induction of $c$-sis and PDGF. ${ }^{4}$ Activated human peripheral blood monocytes, ${ }^{10}$ monocytes matured in vitro, ${ }^{11}$ and activated alveolar and peritoneal macrophages ${ }^{12}$ have all been shown to express c-sis mRNA. Thus, TGF- $\beta$ and $c$-sis mRNA are expressed by non-neoplastic cells of the monocytephagocyte system and appear to play an important role in mesenchymal proliferation. ${ }^{6}$ Since the cellular components and histologic appearance of malignant fibrous histiocytoma (MFH) overlap with those of the inflammatory response, we have investigated whether the molecular mechanisms of proliferation in MFH are analogous to wound repair and thus involve expression of TGF- $\beta$ and c-sis. We have analyzed samples of fresh-frozen tissue from five cases of MFH and two cases of benign fibrohistiocytic tumors for mRNA expression of TGF- $\beta$ and $c$-sis. 
Table 1. Clinical Information

\begin{tabular}{|c|c|c|c|c|c|}
\hline Case No. & Diagnosis & Sex & Age (years) & Site & Diameter \\
\hline 1 & MFH & $\mathbf{F}$ & 71 & Thigh & $8 \mathrm{~cm}$ \\
\hline 2 & MFH & M & 29 & Thigh & $13.5 \mathrm{~cm}$ \\
\hline 3 & MFH & M & 67 & Tibia & Not available \\
\hline 4 & MFH & M & 88 & Buttock & Not available \\
\hline 5 & MFH & M & 65 & Chest & $4 \mathrm{~cm}$ \\
\hline 6 & Fibrous histiocytoma (benign) & $\mathbf{F}$ & 57 & Cheek & $5.5 \mathrm{~cm}$ \\
\hline 7 & Atypical fibrohistiocytic lesion (benign) & $\mathbf{F}$ & 39 & Shoulder & $3.2 \mathrm{~cm}$ \\
\hline
\end{tabular}

MFH, malignant histiocytoma.

\section{Materials and Methods}

\section{Materials}

Frozen tissue was available from I 1 fibrohistiocytic lesions; intact mRNA was obtained from 7 of these. Five of these seven were MFHs, one was a benign fibrous histiocytoma, and one was diagnosed as an "atypical fibrohistiocytic lesion." The five MFHs, designated samples 1-5 (Table 1, Fig. 1), were from four men and one woman whose ages ranged from 29 to 88 years (average, 64 years) and tumor size (where known) ranged from 4 to $13.5 \mathrm{~cm}$. All of the MFHs were high grade. Four cases were of storiformpleomorphic type, and one was a giant cell variant (case 2). The benign fibrous histiocytoma (case 6) was from a 57-year-old woman and measured 5.5 $\mathrm{cm}$, and the atypical fibrohistiocytic lesion (case 7) was from the shoulder of a 39-year-old woman and measured $3.2 \mathrm{~cm}$. The clinical data are summarized in Table 1.

\section{RNA Isolation and Northern Blot Hybridization Analysis}

Tissue was obtained at surgery and snap-frozen in liquid nitrogen and stored at $-70^{\circ} \mathrm{C}$ until used. From each frozen sample approximately $0.5 \mathrm{~cm}^{3}$ of tissue was available for analysis. Total RNA was isolated from each sample using acid guanidinium thiocyanate-phenol-chloroform extraction. ${ }^{13}$ The amount of RNA extracted ranged from 17 to $210 \mu \mathrm{g}$ (average yield, $77 \mu \mathrm{g}$ ). Twenty micrograms of each RNA sample were used for Northern blotting (except for case 7 from which only $16 \mu \mathrm{g}$ were available). Also included was a positive control consisting of $20 \mu \mathrm{g}$ of total cellular RNA from cultured human pulmonary endothelial cells that express c-sis ${ }^{14}$ and TGF- $\beta$ (Kern J., verbal communication, May 1989). In addition, $1 \mu \mathrm{g}$ of each cDNA from which the TGF- $\beta$ and c-sis probes had been prepared were loaded onto the gel as "hybridization controls." A negative control consisted of $20 \mu \mathrm{g}$ of cellular RNA from unstimulated cultured Jurkat $\mathrm{T}$ lymphocytes. The samples were electrophoresed through a glyoxyl-agarose gel $^{15}$ and photographed to determine position of the $28 \mathrm{~S}$ and $18 \mathrm{~S}$ bands, as well as the RNA size marker, and to assess the integrity of the extracted cellular RNA. The RNA was transferred to Gene Screen Plus nylon membranes (New England Nuclear, Boston, MA) following published protocols ${ }^{16}$ and hybridized overnight to $5 \times 10^{6}$ counts per minute of ${ }^{32} \mathrm{P}$-labeled cDNA probes at $42^{\circ} \mathrm{C}$ in a prewarmed, fresh hybridization buffer. ${ }^{32} \mathrm{P}$-labeled probes were prepared by random priming ${ }^{17}$ of the following cloned DNA fragments: human c-sis ${ }^{18}$ in pBR322 (obtained from the Cell Center at the University of Pennsylvania), human TGF- $\beta 1^{19}$ (plasmid sp64, gift of R. Derynck), and human $\beta_{2}$-microglobulin ${ }^{20}$ to check for equal loading of mRNA. After hybridization, filters were washed and exposed to Kodak XAR-2 film (Rochester, NY) at $-70^{\circ} \mathrm{C}$ with two intensifying screens for 3-15 days. Between hybridizations to different probes, filters were stripped with boiling water and reexposed to film for several days to ascertain complete removal of the original probe. Hybridization for the human $\beta_{2}$-microglobulin probe was performed last.

\section{Results}

Intact RNA was obtained from 7 of 11 patients from whom tissue was available, as evidenced by direct visualization of $28 \mathrm{~S}$ and $18 \mathrm{~S}$ bands under ultraviolet fluorescence, as well as by the presence of a band for $\beta_{2}$-microglobulin at the expected size of 1.0 kilobase $(\mathrm{kb})^{20}$ (Fig. 1, bottom). Hybridization for $\beta_{2}$-microglobulin demonstrated comparable amounts of mRNA in each sample lane except for case 7 ("atypical fibrohistiocytic lesion"), from which only $16 \mu \mathrm{g}$ were available. As illustrated in Figure 1 (top), a $4.2 \mathrm{~kb}$ c-sis mRNA transcript ${ }^{21}$ was detected in the positive control cells as expected, but not in the RNA extracted from the MFH samples or the benign fibrohistiocytic tumors. Most of the pa- 

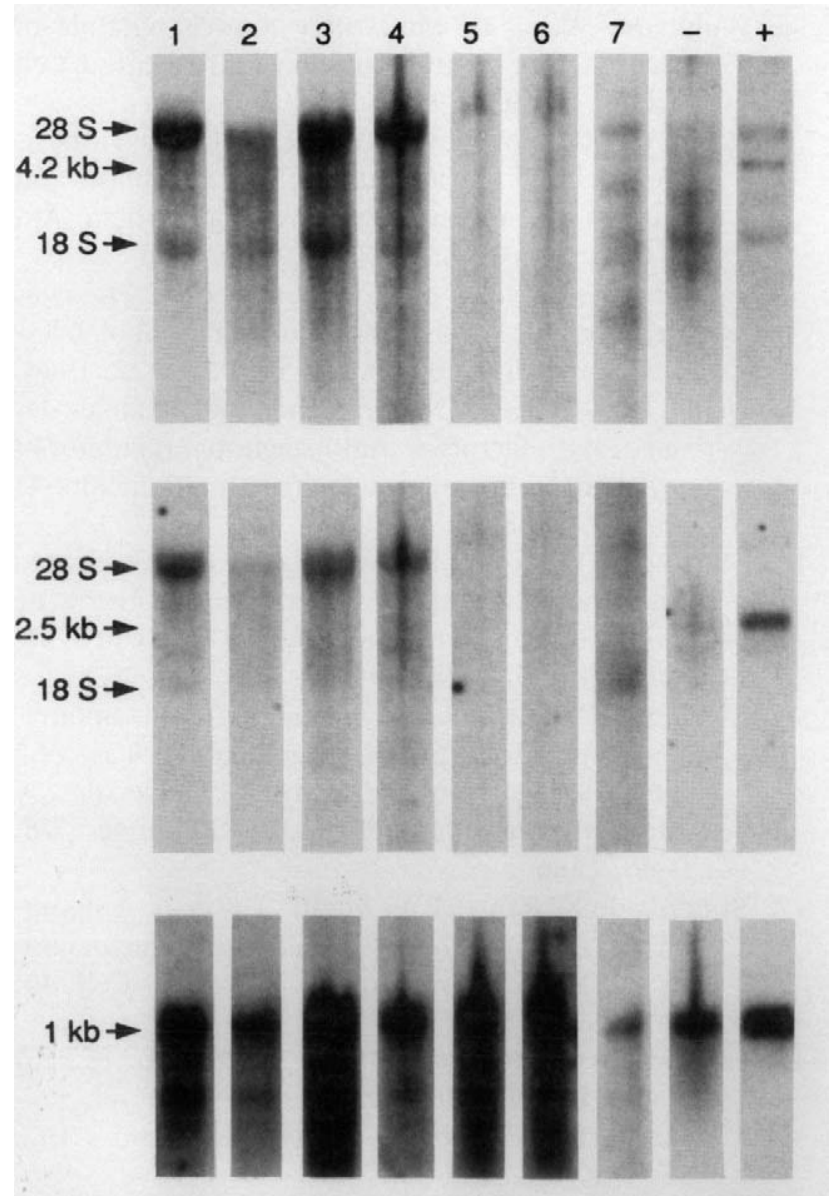

Fig. 1. Northern blot for transforming growth factor- $\beta$ and c-sis expression in fibrohistiocytic neoplasms. Hybridization is seen to $\mathrm{c}$-sis at $4.2 \mathrm{~kb}$ (top) and transforming growth factor- $\beta$ at $2.5 \mathrm{~kb}$ (middle) in the positive control only $(+)$; the tumor samples do not demonstrate specific binding to the probe. Hybridization for $\beta_{2}$-microglobulin (bottom) was performed to ensure comparable loading of the tumor samples (note the lesser amount in sample 7). Exposure times were 15 days for transforming growth factor- $\beta$, five days for $\mathrm{c}$-sis, and 7 days for $\beta_{2}$-microglobulin. Lanes $1-5$ consist of $20 \mu \mathrm{g}$ of total cellular RNA from malignant fibrous histiocytoma tumor tissue (cases 1-5; Table 1). Lane 6 contains $20 \mu \mathrm{g}$ of RNA from a fibrous histiocytoma, and lane 7 contains $16 \mu \mathrm{g}$ of RNA from an atypical fibrohistiocytic lesion. Twenty micrograms of total cellular RNA from cultured human pulmonary endothelial cells and cultured Jurkat $\mathrm{T}$ cells served as positive $(+)$ and negative $(-)$ controls, respectively.

tient samples hybridized to RNA species at approximately 5 and $2 \mathrm{~kb}$, which was interpreted as nonspecific hybridization of the probe to $28 \mathrm{~S}$ and $18 \mathrm{~S}$ rRNA due to the relatively nonstringent hybridization conditions and the large amount of total RNA used for each sample. A faint band running between 3.0 and $4.0 \mathrm{~kb}$ in the atypical fibrohistiocytic lesion (case 7) was similarly interpreted as nonspecific binding. None of the patient samples contained detectable TGF- $\beta$ mRNA at $2.5 \mathrm{~kb}^{19}$ (Fig. 1, middle). A band hybridizing to the probe at approximately $5 \mathrm{~kb}$ in these lanes was interpreted as cross-hybridization to rRNA as above. Although we considered the possibility that this band might represent hybridization to a $5.1 \mathrm{~kb}$ TGF- $\beta 2$ transcript, ${ }^{22}$ the absence of the other TGF- $\beta 2$ bands at 4.1 and $6.5 \mathrm{~kb}$, and the presence of the same size band cross-hybridizing with the c-sis probe indicated that this $5 \mathrm{~kb}$ band was nonspecific.

\section{Discussion}

Although TGF- $\beta^{5,23}$ and $c$-sis ${ }^{24,25}$ mRNA expression have been previously reported in human mesenchymal tumors, to our knowledge no one has studied their expression in resected MFHs. Since TGF- $\beta$ and c-sis are clearly established as mediators of physiologic cellular proliferation, ${ }^{3,6}$ their absence in our MFH samples implies that the normal molecular mechanisms that mediate mesenchymal cell growth are bypassed in MFH.

These findings may have implications regarding the cell of origin of this neoplasm. Malignant fibrous histiocytoma was originally thought to be a true histiocytic neoplasm derived from cells of monocytic cell lineage. ${ }^{26}$ Since TGF- $\beta$ and $c$-sis expression are closely associated with such cells, ${ }^{6,12}$ the absence of their expression in MFH may reflect a nonhistiocytic lineage for this neoplasm. This interpretation is consistent with other studies using a variety of methods, such as electron microscopy, ${ }^{27}$ cell culture, ${ }^{28}$ and immunohistochemistry, ${ }^{29-33}$ that do not support histiocytic derivation of $\mathrm{MFH} .{ }^{27,34-38}$ However, the absence of TGF- $\beta$ and $\mathrm{c}$-sis expression in MFH may simply reflect transformation-associated alterations in gene expression rather than characteristics of the premalignant cell of origin. The true significance of our findings with regard to the histogenesis of MFH would be further supported by a comparative analysis of mRNA expression in proliferating fibroblasts or fibrosarcoma.

One of the authors of this study earlier reported the immunohistochemical identification of PDGF in MFH. ${ }^{39}$ Since c-sis encodes a precursor of the B chain of PDGF, the data presented here might seem to contradict these earlier observations. One possibility is that the presence of PDGF by immunohistochemistry is an artifact due to the endocytotic ${ }^{33,40,41}$ properties of the MFH cell. However, the presence of PDGF in the absence of c-sis is not necessarily a contradiction. The antibodies used in the study cited above were polyclonal to PDGF and are, therefore, likely against 
both A and B chains. C-sis encodes only the B chain of $\mathrm{PDGF}^{8}$ and, in fact, the relationship between csis mRNA expression and PDGF secretion is not as straightforward as was originally thought. ${ }^{42}$ For example, it is increasingly recognized that A-chain homodimers of PDGF-A have biologic activity. ${ }^{43}$ In fact, there is evidence in a number of tumor cell lines, ${ }^{44}$ as well as in human fibroblasts, ${ }^{45}$ that expression of the PDGF A chain is independent of that of the PDGF $B$ chain. We believe that the immunohistochemical identification of PDGF expression by polyclonal antibodies may reflect the presence of A-chain unaccompanied by B-chain (c-sis) mRNA expression. However, Franklin et al. ${ }^{46}$ and Palman et al. ${ }^{47,48}$ recently reported the immunohistochemical identification of the $\beta$-subunit of PDGF receptor, which specifically binds the B chain of PDGF, in several cases of MFH. According to the autocrine hypothesis of soft tissue tumor growth, ${ }^{39}$ the presence of PDGF B-chain receptors in MFH might imply that the tumor cells also produce the PDGF B chain. Further analysis with newer monoclonal antibodies specific for the PDGF $B$ chain, as well as analysis for PDGF A chain and PDGF receptor $\alpha$-subunit expression, will be necessary to fully elucidate the role of PDGF in MFH.

\section{Acknowledgments}

The authors thank Dr. Rik Derynck, formerly of Genentech, for the TGF- $\beta$ probe, Drs. Jeff Kern and Steve Albelda for cultured pulmonary endothelial cells, and Drs. James Alwine and Susan Carswell for their advice and assistance.

\section{References}

1. Sporn MB, Roberts AB. The transforming growth factor-betas: past, present, and future. Ann N Y Acad Sci 593:1-6, 1990

2. Assoian RK, Fleurdelys BE, Stevenson $\mathrm{HC}$ et al. Expression and secretion of type beta transforming growth factor by activated human macrophages. Proc Natl Acad Sci U S A 84:6020-6024, 1987

3. Wahl SM, McCartney Francis N, Allen JB et al. Macrophage production of TGF-beta and regulation by TGF-beta. Ann N Y Acad Sci 593:188-196, 1990

4. Leof EB, Proper JA, Goustin AS. Induction of c-sis mRNA and activity similar to platelet-derived growth factor by transforming growth factor beta: a proposed model for indirect mitogenesis involving autocrine activity. Proc Natl Acad Sci U S A 83: 2453-2457, 1986

5. Roberts AB, Thompson NL, Heine $U$ et al. Transforming growth factor-beta: Possible roles in carcinogenesis. Br J Cancer 57:594-600, 1988
6. Wahl SM, Wong H, McCartney Francis N. Role of growth factors in inflammation and repair. $\mathbf{J}$ Cell Biochem 40:193-199, 1989

7. Raghu G, Masta S, Meyers D et al. Collagen synthesis by normal and fibrotic human lung fibroblasts and the effect of transforming growth factor-beta. Am Rev Respir Dis 140:95-100, 1989

8. Johnsson A, Heldin C-H, Wasteson $\AA$ et al. The c-sis gene encodes a precursor of the $\mathrm{B}$ chain of plateletderived growth factor. EMBO J 3:92 I-928, 1984

9. Deuel TF, Silverman NJ, Kawahara RS. Platelet-derived growth factor: A multifunctional regulator of normal and abnormal cell growth. Biofactors 1 : 213-217, 1988

10. Martinet Y, Bitterman PB, Mornex J-F et al. Activated human monocytes express the c-sis proto-oncogene and release a mediator showing PDGF-like activity. Nature 319:158-160, 1991

I 1. Mornex J-F, Martinet Y, Yamauchi K et al. Spontaneous expression of the $\mathrm{c}$-sis gene and release of a platelet-derived growth factorlike molecule by human alveolar macrophages. J Clin Invest 78 : $61-66,1986$

12. Shimokado K, Raines EW, Madtes DK et al. A significant part of macrophage-derived growth factor consists of at least two forms of PDGF. Cell 43: 277-286, 1985

13. Chomczynski P, Sacchi N. Single-step method of RNA isolation by acid guanidinium thiocyanate-phenolchloroform extraction. Anal Biochem 162: $156-159,1987$

14. Albelda SM, Elias JA, Levine EM et al. Endotoxin stimulates platelet-derived growth factor production from cultured human pulmonary endothelial cells. Am J Physiol 257:L65-L70, 1989

15. McMaster GK, Carmichael GG. Analysis of single- and double-stranded nucleic acids on polyacrylamide and agarose gels by using glyoxal and acridine orange. Proc Natl Acad Sci U S A 74:4835, 1977

16. Sambrook J, Fritsch EF, Maniatis T. Molecular cloning: A laboratory manual. 2nd ed. Cold Spring Harbor Laboratory Press, Cold Spring Harbor, NY, 1989

17. Feinberg AP. Vogelstein B. A technique for radiolabeling DNA restriction endonuclease fragments to high specific activity. Anal Biochem 132:6-13, 1983

18. Dalla Favera R, Gallo RC, Giallongo A. Chromosomal localization of the human homolog (c-sis) of the simian sarcoma virus onc gene. Science 218: $686-688,1982$

19. Derynck R, Jarrett JA, Chen EY et al. Human transforming growth factor-beta complementary DNA sequence and expression in normal and transformed cells. Nature 316:701-705, 1985

20. Suggs SV, Wallace RB, Hirose $T$ et al. Use of synthetic oligonucleotides as hybridization probes: isolation of cloned CDNA sequences for human beta 2-microglobulin. Proc Natl Acad Sci U S A 78:6613-6617. 1981

2 I. Graves DT, Owen AJ, Barth RK et al. Detection of csis transcripts and synthesis of PDGF-like proteins 
by human osteosarcoma cells. Science 226 : 972-974, 1984

22. Madisen L, Webb NR, Rose TM et al. Transforming growth factor-beta2: cDNA cloning and sequence analysis. DNA 7:1-8, 1988

23. Derynck R, Goedel DV, Ulrich A et al. Synthesis of messenger RNAs for transforming growth factors alpha and beta and the epithermal growth factor receptor by human tumors. Cancer Res 47:707, 1987

24. Eva A, Robbins KC, Andersen PR et al. Cellular genes analogous to retroviral onc genes are transcribed in human tumour cells. Nature 295:116, 1982

25. Fahrer C, Brachmann R, von der Helm K. Expression of $\mathrm{C}$-sis and other cellular proto-oncogenes in human sarcoma cell lines and biopsies. Int $\mathrm{J}$ Cancer 44:652-657, 1989

26. Ozello L, Stout AP, Murray MR. Cultural characteristics of malignant histiocytomas and fibrous xanthomas. Cancer 16:331-344, 1963

27. Taxy JB, Battifora H: Malignant fibrous histiocytoma: An electron microscopic study. Cancer 40: 254-267, 1977

28. Roholl PJ, Kleyne J, Van Blokland M et al. Characterization of two cell lines, derived from two malignant fibrous histiocytomas. J Pathol 150:103-112, 1986

29. Brecher ME, Franklin WA: Absence of mononuclear phagocyte antigens in malignant fibrous histiocytoma. Am J Clin Pathol 86:344-348, 1986

30. Wood GS, Beckstead JH, Turner RR et al. Malignant fibrous histiocytoma tumor cells resemble fibroblasts. Am J Surg Pathol 10:323-335, 1986

31. Roholl PJ, Kleyne J, Elbers $\mathrm{H}$ et al. Characterization of tumour cells in malignant fibrous histiocytomas and other soft tissue tumours in comparison with malignant histiocytes. I. Immunohistochemical study on paraffin sections. J Pathol 147:87-95, 1985

32. Roholl PJ, Kleyne J, Van Unnik JA. Characterization of tumor cells in malignant fibrous histiocytomas and other soft-tissue tumors, in comparison with malignant histiocytes. II. Immunoperoxidase study on cryostat sections. Am J Pathol 121:269-274, 1985

33. Roholl PJ, Kleyne J, van Basten CD et al. A study to analyze the origin of tumor cells in malignant fibrous histiocytomas. A multiparametric characterization. Cancer 56:2809-2815, 1985

34. de Boulay CE. Demonstration of alpha-1-antitrypsin and alpha- I-antichymotrypsin in fibrous histiocytomas using the immunoperoxidase technique. Am J Surg Pathol 6:559-564, 1982

35. Strauchen JA, Dimitriu Bona A. Malignant fibrous his- tiocytoma: Expression of monocyte/macrophage differentiation antigens detected with monoclonal antibodies. Am J Pathol 124:303-309, 1986

36. Iwasaki $\mathrm{H}$, Kikuchi $\mathrm{M}$, Takii $\mathrm{M}$ et al. Benign and malignant fibrous histiocytomas of the soft tissues: Functional characterization of the cultured cells. Cancer 50:520-530, 1982

37. Kindblom LG, Jacobsen GK, Jacobsen M. Immunohistochemical investigations of tumors of supposed fibroblastic-histiocytic origin. Hum Pathol 13: 834-840, 1982

38. Tanaka H, Mori $Y$, Akedo H. Histiocytic differentiation of mouse malignant fibrous histiocytoma-like tumor cells by culturing with sodium butyrate. Cell Biol Int Rep 6:85-89, 1982

39. Perosio PM, Brooks JSJ. Expression of growth factors and growth factor receptors in soft tissue tumors: Implications for the autocrine hypothesis. Lab Invest $60: 245-253,1989$

40. Soini Y, Miettinen M. Alpha-l-antitrypsin and lysozyme: Their limited significance in fibrohistiocytic tumors. Am J Clin Pathol 91:515-521, 1989

41. Brooks JSJ. Immunohistochemistry of soft tissue tumors: progress and prospects. Hum Pathol 13: 969-974, 1982

42. Leveen P, Claesson Welsh L, Heldin C-H et al. Expression of messenger RNAs for platelet-derived growth factor and its receptors in human sarcoma cell lines. Int $J$ Cancer 46:1066-1070, 1990

43. Heldin C-H, Johnsson A, Wennergren $\mathrm{S}$ et al. A human osteosarcoma cell line secretes a growth factor structurally related to a homodimer of PDGF Achains. Nature 319:511-514, 1986

44. Betsholtz C, Johnsson A, Heldin C-H et al. cDNA-sequence and chromosomal localization of human platelet-derived growth factor A-chain and its expression in tumour cell lines. Nature 320 : $695-699,1986$

45. Paulsson $\mathrm{Y}$, Hammacher A, Heldin C-H et al. Possible positive autocrine feedback in the prereplicative phase of human fibroblasts. Nature 328:715-717, 1987

46. Franklin WA, Christison WH, Colley $M$ et al. In situ distribution of the beta-subunit of platelet-derived growth factor receptor in nonneoplastic tissue and in soft tissue tumors. Cancer Res 50:6344-6348, 1990

47. Palman C, Bowen-Pope DF, Brooks SJ. Platelet-derived growth factor receptor expression in soft tissue tumors. Lab Invest 62:77A, 1990 (Abstract)

48. Palman C, Bowen-Pope DF, Brooks SJ. Platelet-derived growth factor receptor ( $\beta$-subunit) immunoreactivity in soft tissue tumors. Lab Invest 66 : $108-115,1992$ 